\title{
Sustainability of the Black Press as Social Justice: A Digital Technology Gap Study
}

\author{
Indhira Suero Acosta \\ Santo Domingo Institute of Technology - indhira.suero@intec.edu.do
}

Bernardo H. Motta

University of South Florida St. Petersburg - bhmotta@mail.usf.edu

\begin{abstract}
The National Newspaper Publishers Association (NNPA) enlists a total of 157 members - publications directed to the African-American community in the United States. There is currently no research on how these publications have adopted technology through time, or if the adoption of new media contributes to their growth and survival in the publishing industry. In Florida, The Weekly Challenger, Daytona Times and Florida Courier, three of 13 historical newspapers, are connected in history and structure and show different types of survival methods. How have these publications adopted technology through time? What types of trends are reflected in these newspapers? What challenges are faced

by the Black community weeklies? To answer these questions, the authors conducted case studies employing participant observation, lengthy interviews, historical research and qualitative questionnaires. A significant finding of this research demonstrates the difficulty to get responses due to suspicion and intimidation from the targeted audience. These newspapers struggle with a diminished workforce who lack professional and technical training and must perform multiple roles. Findings also show that 14 of the newspapers listed as current NNPA members are not currently in circulation and that the publications' pattern of adoption is not planned, but a consequence of availability and chance.
\end{abstract}

Keywords: Internet, journalism, black press, African-American newspapers, Afro-newspapers

\section{A Sustentabilidade da Imprensa Negra como Justiça Social: Um Estudo Sobre o Hiato na Tecnologia Digital}

\section{Sumário}

A National Newspaper Publishers Association (NNPA) conta com um total de 157 membros - publicações dirigidas à comunidade afro-americana nos Estados Unidos. Atualmente, não há pesquisas sobre a forma como essas publicações adotaram a tecnologia ao longo do tempo ou se a adoção dos novos média contribui para seu crescimento e sobrevivên- 
cia na indústria editorial. Na Flórida, o The Weekly Challenger, o Daytona Times e o Florida Courier, três dos 13 jornais históricos, estão conectados na história e na estrutura e mostram diferentes tipos de métodos de sobrevivência. Como é que essas publicações adotaram a tecnologia ao longo do tempo? Que tipos de tendências são refletidas nesses jornais? Que desafios são enfrentados pelos semanários da comunidade negra? Para responder a essas perguntas, os autores realizaram estudos de caso utilizando observação participante, entrevistas longas, pesquisa his- tórica e questionários qualitativos. Uma descoberta significativa desta pesquisa demonstra a dificuldade em obter respostas, devido à suspeita e intimidação do público-alvo. Estas publicações lutam com uma força de trabalho reduzida, que não tem treino profissional e técnico e deve desempenhar várias funções. Os resultados também mostram que 14 dos jornais listados como membros atuais da NNPA não estão atualmente em circulação e que o padrão de adoção das publicações não é planeado, mas uma consequência da disponibilidade e do acaso.

Palavras-chave: Internet, jornalismo, imprensa negra, jornais Afro-Americanos, Afro-jornais

According to the National Newspaper Publishers Association (NNPA), there are more than 200 local and regional publications directed to the African-American community in the United States. On its website, the NNPA enlists a total of $157 \mathrm{mem}-$ bers from 29 states.

There is currently no research on how these publications have adopted technology through time, or if the adoption of new media contributes to their growth and survival in the publishing industry. In a time when relevant and larger newspapers have disappeared or merged with bigger papers - and as their intended audience shows changing patterns in the way that they consume the news - most of these Afronewspapers continue as print community weeklies that they must adapt to maintain their readership. To survive and hopefully thrive, ethnic presses must change the ways that they gather information, produce the articles, publish the newspaper and organize their staff.

A significant finding of this research demonstrates the difficulty to employ quantitative methods with this audience due to suspicion and intimidation from the indi- 
viduals. The results of this study also indicate that besides facing old challenges, such as lack of advertisement, financial pressure and declining staff, these papers have been struggling with a diminished workforce who lack professional and technology training and must perform multiple roles in the organization. Findings also show that 14 of the publications listed on the NNPA list aren't currently in circulation and that the newspapers' pattern of adoption is not planned, but a consequence of availability and chance.

In Florida, three of 13 historical newspapers directed at the African-American population are connected in history and structure and show different types of survival methods and ways of adopting new technologies.

The Weekly Challenger, in St. Petersburg, bought by the publisher Cleveland Johnson Jr. in 1967 and serving the African-American communities in South St. Petersburg. The Daytona Times (1969), first Afro-newspaper in Daytona Beach, and the Florida Courier (1989), the first Black newspaper in Florida to go statewide. The civil rights activist Charles Cherry founded both. These three publications also share characteristics: small family business that faced new challenges after the death of their founders, and that continued thanks to the families' matriarch's decision.

How have these publications adopted technology through time? What types of trends are reflected in these publications? What problems are faced by the Black community weeklies? What challenges are faced in getting responses to the research? This study addresses these questions.

\section{LITERATURE REVIEW HISTORY OF THE BLACK PRESS}

In The African American Newspaper: Voice of Freedom, Washburn (2006), wrote that to figure out where Black media, as well as any other media, are going in today's world, it is helpful to know where they have been. Washburn (2006) described the origins:

The publication of America's first (B)lack-owned newspaper, Freedom's Journal, in 1827 gave African Americans a voice of their own to 'plead our own cause' in the words of editors John Russwurm and Samuel Cornish. From then to now, (B)lack newspapers offered passionate advocacy for (B)lack rights, opportunities, and visibility against the community's common enemies. 
Agreeing with the importance of the African-American press for molding selfesteem, opinion and setting public agenda, in 1990, Dates wrote that between the first emergence of Freedom's Journal in 1827 and the Civil War, around forty Black newspapers were published with anti-slavery titles such as Alienated American, Mirror of Liberty and Freeman's Advocate, among others. The exact number of press during that period is still a matter of discussion among historians.

According to Dates (1990), "many of them had limited lives and would not be considered newspapers in the current sense of the word, but they served to create a print institution for the expression of views controlled by (B)lack people. All of these papers, because of their limited markets, were under extreme financial pressure."

The glory days of the African-American press began during the 1920s and 1930s. According to Muhammad (2003), during those decades, Black publishers augmented their incomes and acquired power among other members of their society: "Robert S. Abbott started The Defender with $\$ 13.75$ and became one of America's first (B) lack millionaires. By 1929, The Defender circulation was 230,000 a week, but the Pittsburgh Courier was biggest, topping 300,000 with 15 editions across the country."

During the World War II, all African-American newspapers experienced an increase in circulation and actively supported the war effort. After the combat finished, newspapers like the Pittsburgh Courier, the [Baltimore] Afro-American, The Chicago Defender, and the New York Amsterdam News gained more popularity among their communities. Dates also noted that once the conflict against foreign fascism ended the Black press was stronger than it had ever been and questioned more vigorously the domestic apartheid that existed. Dates (1990) asserted that:

At the beginning of 1948, there was a total of 169 newspapers, 56 college campus publications of all types, and more than 100 religious, fraternal, general and other papers, bulletins and magazines. But in 1954 the first hint came that this situation would not last forever. The NAACP raised the issue of the legality of segregated schools in the case of Brown v. the Board of Education.

The quest end of segregation was not the only factor that contributed to the dwindling of these type of newspapers from the late 1940s until the mid-1960s. The African-American press was no longer alone in the Black community's terrain; it faced the uprising of other types of general media, such as the radio, television, and magazines. 
Socio-political changes also added new challenges. For example, Muhammad (2003) wrote that the bright days in Black media changed even more by the Black Power era:

The (B)lack press was considered, at best, a farm team for major dailies, which recruited top (B)lack journalists to cover the civil rights movement and eventually attracted readers and advertisers once considered the (B)lack press's captive market. Conventional wisdom by the 1980's was that the (B)lack press, by doing such a bang-up job promoting racial equality, had made itself obsolete.

According to Wilson II (2014), despite the numerous challenges faced by the Black papers in the second half of the 20th century and beyond, success stories can still be found in some examples of African-American newspapers founded before 1935 that have survived into the second decade of the 21 st century.

The authors also listed the publications currently operating. Among the titles Wilson II mentioned were: Atlanta Daily World (1928), Baltimore Afro-American (1892), Charlotte Post (1878), The Chicago Defender (1905), Cleveland Call and Post (1928), Houston Defender (1930), Indianapolis Recorder (1806), Kansas City Call (1919), Los Angeles Sentinel (1933), Miami Times (1923), New York Amsterdam News (1909), Philadelphia Tribune (1884), Pittsburgh Courier (1910) and The St. Louis American (1928). Besides, Wilson mentioned that the emerging new Afro-American newspapers struggle with six different factors: operating under a capitalistic environment; lack of investment from industries and corporations; White-owned media appropriating Black businesses; confusion in what constitutes the Black press; lack of reporting/editing staff; and difficulty to achieve an in-depth reporting.

Determining the exact quantity of African-American publications across the United States represents another challenge for the industry. In 2016, Vogt wrote that during 2015 the National Newspaper Publishers Association (NNPA) tracked the number of African-American publications at around 200. According to Vogt (2016), only a handful of historically prominent Black papers have regularly audited circulation figures. This low percentage affects the capability to obtain industry-wide measures. She also mentioned that those calculations showed some audience decline in 2015. 


\section{TECHNOLOGY IN THE BLACK PRESS}

Wolseley (1990), also wrote about the future of the Black papers and expressed his predictions during the 1990s. Wolseley's research - published in 1990 - was confined exclusively to the print media and did not include electronic journalism: "They fall in three groups: the press will disappear, it will diminish but survive, or it will be a strong element in communication in this country." The researcher also explained that, during that time, the American Black press confronted a public split never seen before with a large middle-class group. On one side; a small group composed of militant Blacks who wanted change; and a third group, not part of its potential audience, representing the lower socio-economic and population with limited education that generally reframed from reading newspapers at all.

In 2008, Everett argued that the Black press was yet again at the forefront of a bold, different migration. Despite the integration of newsrooms that took the talented writers from Black newspapers; the apparent devastation of the historic AfricanAmerican press, and the remaining reporters' refusal to be forced into oblivion by mainstream and new digital media technologies the Black papers adapted to their new environment. Everett also studied the transition from print to digital media for two established Black publications, The Charlotte Post and Afro-Americ@n, "one of the first established newspapers, Black or White, to go online."

Wilson II (2014) wrote that by 2010 many of the more economically stable AfroAmerican papers had transitioned to producing digital online versions to complement their print editions. The issue, back then, was that only a small percentage of Black weeklies have taken that transitional step and the prospective advertisers did not believe that an economically viable African American demographic accessed the online sites.

Regarding demographics, Vogt (2016) explained that from 2014-2015, there were virtually equal shares of profits and losses relating to the number of unique visitors and the minutes per visit that readers spent with a group of 14 outlets of African-American media.

According to her research:

When it came to mobile traffic, the majority of sites (10 of the 14) experienced an increase in unique visitors, and eight of these sites showed an increase of $10 \%$ or greater from the previous year. For 11 of 14 of the outlets, however, the number of unique visitors from desktops fell, with eight showing a drop of $10 \%$ or greater from the fourth quarter of 2014 to the fourth quarter of 2015. 
As a side note, Vogt reported that in March 2016, the Poynter Institute and the National Association of Black Journalists announced that they would join to provide leadership training to journalists of color working in digital media.

Citing Everett, 2008, the portrait of the migration to the Internet of The Charlotte Post and the Afro-Americ@an's "clearly reveals their commitment to continue the struggle for (B)lack political, social, cultural and economic survival and prosperity into the digital age."

\section{TECHNOLOGY IN THE NEWSROOM AND A NEW TYPE OF READER}

Not only the African-American press faces challenges of adapting to a new media landscape. New technologies will always present defiances for the newsrooms. Mari (2017) considered that the adoption and use of telephone technology was part of a long-established pattern of news workers using technology to increase their storytelling potential, but they also required new ways of acculturating young reporters to their effective use, and helped establish new routines built out of and on top of (or sometimes within) older ones:

Reporters and editors sometimes resisted, and at other times coopted, these changes. Coming into a space already structured by both vertical and horizontal hierarchies of power, the potential of radio, the car, and then the radio car was mitigated and molded by an existing culture of work practices. It accelerated and then cemented the separation of news gathering from news production, and set the stage for the computerization of the Newsroom.

For Spyridou, Matsiola, Veglis, Kalliris and Dimoulas (2013), findings suggest that professional culture, articulated in skills, ideas and practices, acts as a network that weakens the potential impact of technology towards innovation and audience-oriented models of journalism. The results of her study point to the conclusion that "the internet and related tools are seen as empowering journalists to do their (traditional) jobs better instead of moving on to the next stage built around a stronger commitment to capitalize on the growing socio technical potential."

In a similar vein, Garrison (2001) examined hundreds of newspapers adoption of technology in the U.S. between 1994 and 1999 applying Everett Rogers' approach to 
the Diffusion of Innovations Theory. Garrison's longitudinal study demonstrated that diffusion of innovations in newsrooms caused a significant redefinition of newsroom roles an occupational categories thanks to the introduction of computers and online search engines. In what is more relevant to this particular study, Garrison highlights the reasons managers gave for non-adoption of new technologies:

Often, non-adoption decisions are made because of a perceived low rate of diffusion, bad information, and a bad price and bad value ratio, Mahler and Rogers (1999) observed. Reasons cited for not adopting online resources in newsrooms included reluctance by management to lead toward adoption, lack of resources to invest in new technology, lack of training, little or no access to the new technology, lack of expertise, fear of lost time required to learn, and not enough time in the work schedule (Garrison, 1998). A news organization that embraces the web and other forms of online information-gathering can overcome these barriers. (Garrison, 2001, p. 234)

Following up with Garrison's extensive work, Hansen, Paul and Neibergall (2003) surveyed newsrooms and obtained a baseline on six critical areas of information practices: access, training, quality, archiving, revenue, and alerts. They found out that, aside from access, which had been improved by online services and libraries, newsrooms still need to work on the remaining five, especially revenue and alerts. Even access may still be an issue if other categories are not properly developed:

For example, if journalists have comprehensive access to information resources but little opportunity for training in how best to use them, it is a diminished opportunity. Information companies lacking the process to ensure the accuracy and quality of their information products are not serving the public well. (Hansen, Paul, \& Neibergall, 2003, p. 46)

According to Abernathy (2014), for mainstream community newspapers to survive and thrive in the digital era, they need to concentrate investment on content creation and aggregation based on how rapidly their customers' habits and expectations are changing. Abernathy studied the cases of community weeklies employing new technologies and multimedia platforms. Some of the presses cited by her include: The News Reporter (one of the first, small, non-daily newspapers in North Carolina 
to establish a website in 1998 and later a Twitter feed), La Raza (a Spanish-language weekly), Hampshire Review, The Pilot, The Polish Daily News, and Columbia Daily Herald.

Muse Abernathy wrote about the results of a 2009 survey conducted by the University of North Carolina at Chapel Hill that reflected changes in the readers' use of new media. She stated, "like their city kinfolk, rural residents are addicted to texting, Facebook, and smartphones. They estimated that they were spending two hours or more daily with new media, with cellphones and smartphones coming in first followed by social networking, searches, and e-commerce done on desktop computers."

The increase of the online audience through mobile devices constituted a relevant aspect treated by the Pew Research Center State of the Media Reports (2016), which indicated that for 39 of the 50 newspaper websites examined in 2015, "the number of unique visitors on desktop [sic] fell, with 28 showing a drop of at least $10 \%$. Conversely, unique visitors on mobile rose for 43 of the 50 , with 35 showing a $10 \%$ or greater increase." Indeed, Hendricks (2010) wrote that for traditional media outlets, the implications of new media are far-reaching: "New media technologies are being integrated into existing industry operations through media convergence, but in some situations, new media are actually replacing traditional media operations both within organizations and consumers." Furthermore, Pavlik (2013) - citing Heather Scofield - wrote that early evidence suggests that "the digital innovation by traditional print news media is successful in not only building an audience but also generating online advertising revenue."

By 2016, the situation remained similar to the trend perceived in previous years. For example, as of early 2016, just two-in-ten adults in the United States often obtained news from print newspapers while in 2013 the percentage was of a 27\%: "when compared with print, nearly twice as many adults (38\%) often get news online, either from news websites/apps (28\%), on social media (18\%) or both. ( $81 \%$ of adults ever get news on these online platforms.)" Age also represented a determinant factor in the way that readers get their news on mobile devices instead of desktop computers: "Fully seven-in-ten of those ages 18-29 either prefer or only use mobile for getting their digital news, compared with 53\% of those $30-49,29 \%$ of those $50-64$ and just $16 \%$ of those $65+. "$

Findings suggest that professional culture - articulated in skills, ideas and practices - acts as a network that weakens the potential impact of technology towards 
innovation and audience-oriented models of journalism. The results point to the conclusion that the internet and related tools are seen as empowering journalists to do their (traditional) jobs better instead of moving on to the next stage built around a stronger commitment to capitalize on the growing socio technical potential.

Regarding the African-Americans, survey data from 2013 referred that this population was more likely than web users overall to access social media tools such as Twitter and Facebook.

Two digital areas where the (B)lack news media may find a large audience are [on] social networks and in the tablet realm. While African Americans still access the (I)nternet at lower rates than the (W)hite population [70\% of African Americans say they use the (I)nternet, compared to $81 \%$ of non-Hispanic (W) hites], those on the (I)nternet are more likely to use social networks like Facebook, Google+, Twitter and Instagram than whites and the population over all, according to 2012 surveys from the Pew Research Center.

A Nielsen study (2015) indicated that during a time when digital is dominating news media consumption, African-American consumers still trust print with 52\% of the Black audience "more likely to be voracious readers of magazines, which is $30 \%$ higher than the general population." At the same time, the research indicated, African-American consumers have embraced technology, are avid users in this space, and have become vocal mainstays in popular social media and blogging channels.

Smartphone penetration is $81 \%$, slightly edging the total population by $7 \%$. On a monthly basis, (B)lacks spend close to 56 hours using apps or mobile Internet browsers on their smartphones and about two and a half hours watching videos on their smartphones. Additionally, $81 \%$ of African-Americans are more likely to show support for a favorite company or brand using social media, and $76 \%$ are more likely to share opinions by posting reviews and ratings online. 


\section{STATEMENT OF RESEARCH QUESTION AND METHODOLOGY}

\section{Research Question}

How have Black press newspapers The Weekly Challenger, Daytona Times and Florida Courier adopted technology throughout time?

\section{Case Studies}

The authors selected The Weekly Challenger as the only publication directed to the African-American community in Pinellas County, a metropolitan county in the Tampa Bay region along the west coast of Florida. The Daytona Times shares a similar foundational history with The Weekly Challenger and also targets one county, Volusia, on Florida's east coast, while the Florida Courier changed into a statewide weekly publication, in 2006, this transition introduced the paper to new types of challenges (Deggans, 2005). The researchers spent time observing the workflow of The Weekly Challenger to observe how the newsroom, which is actually the publisher's home, worked with technology and conducted in-depth interviews with the editor of the Daytona Times and Florida Courier, Jenise Morgan, reporter Andreas Butler, photographer Duane C. Fernandez and designer Lorrie Bellinger, followed by interviews with the publisher of The Weekly Challenger, Lyn Johnson, and the web and social media manager, Kaye Brown. The observation and all interviews were conducted in 2017 with the interest of having a general idea of technology adoption in AfricanAmerican press rooms. In addition to the interviews, the authors also reviewed oral history pieces and old newspaper articles of the three publications.

\section{Semi-structured Questionnaire}

A semi-structured questionnaire was developed to keep maintain the comparison between all three news organizations consistent.

1) Open-ended questions for a category: Describe how you (perform an action/ activity in this category).

2) Probing questions about technology: What (technology: hardware/software) do you use to perform the action/activity? Describe how you use it.

3) Probing questions about history of an action/activity: How was this action/ activity originally performed?

4) Probing questions about the history of the use of technologies: When did you first start using this (hardware/software) to perform this action/activity? 
How did that change the way you perform the action/activity?

5) Open-ended requests for further details: What else can you tell me about this (activity/technology)?

\section{Online structured questionnaire}

With the goal to develop a baseline for comparison and to test the viability of other research methods, a qualitative questionnaire was developed based on the findings of the case studies. This structured online questionnaire asked specific questions about digital media adoption and usage, the ability of the staff to use digital media (skills, time availability, enough staff members, etc.) and other specific questions related to obstacles for adopting digital media tools.

The distribution list was created from the list of Black Press newspapers on the NNPA website and the Florida Black-Owned Media (FLABOM). Filtering for only currently working news organizations with working contact information, the questionnaire was submitted to 52 companies $(\mathrm{N}=52)$, with weekly reminders for three weeks, which resulted in 7 completed questionnaires $(n=7)$. From the initial 163 members listed on the NNPA's website, 14 have been inactive for years. Eight didn't have any web presence or contact information to be found. A few had disconnected phone numbers. As the authors called, many others would hang up or say they believed the researchers were scamming them. Usually, this part wouldn't make the paper to be presented, but this reaction was predicted and expected due to well-documented and justified historical, cultural and social issues identified earlier in this paper for a natural suspicious reception of strangers trying to acquire information from them. It is an essential note as this affects how researchers need to proceed in the future if they are to obtain accurate and fair data from these companies. This will be addressed in the Discussion section.

\section{FINDINGS}

\section{Online questionnaire}

The online questionnaire indicated a variety in the type of browser, version, operating system and resolution used by these organization. Three of the respondents use Safari, three MSIE, and one Edge. Regarding the operating system, three of these entities use Macintosh, one Windows NT 10.0 and three Windows NT 6.1. 
The location of the organizations' headquarters also varies. The places: Mobile, Alabama; Tampa, Florida; Charlotte, North Carolina; Omaha, Nebraska; Odessa Florida; Indianapolis, Indiana and Los Angeles, California. The questionnaires reported that five of the newspapers are a family owned business. Regarding each organization's type of audience, responses also vary although African-Americans communities are their primary targeted public, with only one paper directed, on a $15 \%$, to the White population and $5 \%$ of other races. The difference is evident in the targeted reader's ages with one newspaper directed primary to African-Americans over 50 years old.

In the question regarding the respondents' role in the organization, multitasking was evident. Five of the surveyed were employed as editors, but are also in charge of proofreading, writing, publishing, designing, photography, and personnel. Only one was a CEO, in charge of the overall effectiveness of operations and administration. While another one was an account executive.

Regarding the number of people employed by their companies the amount also varies. One publication listed "more than 30," while the others were within the range of 30 to eight staff members, freelancers and associates working either for their organization or with the organization.

With the main distribution platforms, four of respondents indicated a weekly print newspaper. Only one pointed out that their primary platform is an online multiplatform and two indicated other types of distribution. One of them a combination of a monthly print newspaper, a weekly website, and a daily social media and internet radio station. The other one is a print newspaper and a monthly minority business magazine. In regards to how well the organizations use online digital media platforms and technologies, two stated that they use Snapchat "extremely well," one "moderately well," and four don't use it. Twitter and Facebook were the most used social media, while some use Instagram and video platforms (i.e., Youtube, Vimeo, etc.) "moderately well," and others don't use it.

Four of the newspapers don't use any digital security system (i.e., Securebox, Signal, etc.) or data visualization program (i.e., Tableau, Infogram, etc.). With Analytics, Proprietary Apps for IOS, Android and Windows, Cloud data management systems and Website builders the responses between organizations that use it and others that don't.

With the use of social media, six of the respondents indicated that they started using it as a regular adopter, specially after seeing their success in the audience. Some of the newspapers used Facebook and Twitter more than their news cycle, while others used it with their news cycle. 
The biggest challenge, according to the surveyed, consisted in adopting new technologies; teaching old staff to employ social media and other digital media; keeping content updated and posted; lack of staff; and the cost on acquiring and implementing new technologies.

\section{Case Studies}

The study conducted questions regarding information gathering, production, publication, and organizational methods. The three weeklies run with a staff of fewer than ten persons. Their editors expressed multiple jobs, apart from editing. In spring 2017, The Weekly Challenger runs with a staff of two employees. The Daytona Times and, her younger sister, Florida Courier, share part of their staff. The papers also rely on freelance reporters and occasionally, on hired photographers. The journalists, designers, and photographers, except for the Times and Courier editor, reported not having any written contract, nothing other than a verbal agreement. The newspapers' print version comes out every week, with different days depending on the paper. None of the publications owns an office, and their staff works from their homes, communicating through email and phone calls, with occasional face-to-face meetings.

The newspapers reported to use Google and Yahoo to gather information, but all of them write their articles from information directly gathered by the journalists, public phone class or press releases. Most of their background research is done on other newspapers websites. All of the papers rely heavily on the other reporters to do one-on-one interviews. Other tools employed were digital recorders, notebooks and photos taken by staff. The Times and the Courier are subscribers of Tribune News Services, a provider of stock photos, but The Challenger does not employ this method. None of the newspapers used scanning methods, recording apps or other digital or smartphone tools. The staffs reported using wireless and cellular telephone networks to do their work, as well as hard-wired. Johnson reported that to write her articles, she presently uses Microsoft Word and Google Documents. Morgan relies on Word. Regarding layout and design software, Bellinger explained that she uses QuarkXPress, Photoshop and an iMac for graphic design. The Daytona and Florida Courier use InDesign, but their photographer does not use Photoshop.

All of the publications use social media for promotional purposes. (Facebook, Twitter, and YouTube), as well as email marketing (newsletters). As of March 2017, The Challenger usesGoogleAnalyticstomeasureitsonlinemetrics. Thehardwareusedtoproducethestories (computers, cameras, recorders) belongs to each staff member, except for the Mac used for 
The Weekly Challenger design. None of the staff uses fax machines in any appreciable way. When the Courier and The Times' editor mentioned that "all of us use Macs," she meant the people that worked on the production side, such as the publisher or the graphic designer. Whereas that, the reporter mentioned having an old Gateway machine.

The Weekly Challenger has a mobile app, but it was not clear for the other newspapers editor if they had one. The three papers hire printing facilities to print their work. The Times and the Courier maintain a Dropbox account and also use FTP as a backup site. The Challenger does not employ these cloud storage services.

\section{DISCUSSION}

The process of developing and distributing the online questionnaire after completing the case studies was particularly meaningful to this research. Many times, the researchers heard from people working in Black Press news media that getting responses for our questionnaire would be very hard primarily due to a lack of trust, but also due to the busy schedules of editors, publishers and reporters in these companies. As in all African-American history, the Black Press has also experienced a long history of abuse and aggressive tactics used against their organizations. Nonetheless, it was essential to test empirically if it would be feasible to create long-distance instruments that could generate generalizable data in the future. The result of multiple attempts, even when negotiated by common acquaintances and intermediaries, was as expected and foretold. This matters as, instead of relying solely on the historical and anecdotal data, it was possible to at least test a few pathways for future research, demonstrating that research done with victimized populations that have in any number of ways requires building trust, cultural learning, and more in-depth methodological conversations that are less appealing to researchers who are time and resource constrained. By its nature, it creates a research bias against engaging with people and organizations in a process that may attract fewer funders and result in fewer publications at the same time that may prove too complicated and taxing for a semester or even year-long projects.

The online questionnaire' responses show that even though many of these news companies may be at different stages of technology adoption in the newsrooms, almost all of them have been following a haphazard or non-structured process in adopting them. Complementing the case studies findings, there seems to be some thinking about technology adoption, but no structured process in planning it for the 
long term. The Weekly Challenger made most of its jump to a more digital platform in 2001 when they had an editor who was knowledgeable and fluent in newsroom technology. Others adopted free tools, such as Facebook, in the same way, consumers would. They all agree that costs (money), training (knowledge), and availability of personnel (time) are the main barriers to adoption. The findings from the case studies seem to show that there is very little being done in thinking of technology of ways to solve the obstacles they have identified, which would be a significant next step for this research. Transforming technology itself in ways to improve profits and profit margins, obtaining knowledge and creating time availability would likely benefit these companies while also bringing them up to speed with the technology they currently miss or don't use to its full potential.

\section{CONCLUSION}

The results of this study indicate that there is a significant gap in the research about the Black press and its use of technologies. It also identified many obstacles to many traditional forms of analysis and sampling. The findings suggest that case studies, ethnographies, and other qualitative and critical methods may be needed to establish lines of trust, which, in the future, may create the foundations for generalizable research. Future researchers working on this topic could focus on understanding how, not only the Black Press but the African-American community as a whole, has managed or coped with constant changes in technologies and related training.

The Courier case, with all of its staff working from different locations, could lead to new studies regarding the impact that new technologies have in the new organizational models in which many of these papers now operate within.

Other challenges to be addressed include the reliance on sources such as Google due to the cost of obtaining syndicated news. The comfort level that reporters have with working outside of the newsroom with limited resources, such as lack of Internet at home, or trying to verify and authenticate information from a source that may not be located within arm's reach of the reporter, but emanating instead, from the other side of a tweet.

There is also a considerable amount of historical work that could help to trace the road traveled by these press survivors and to figure out where their steps will lead them. Researchers need to find ways to and examine these papers' organizational 
work and evolution from inside the newsrooms (or wherever the work happens) to understand and preserve their history while also paying attention to how they move forward in the 21st century.

Finally, as mentioned in the Discussion, obstacles to research resources need to be addressed. This action should be taken to attract and encourage new researchers to assume on the challenge of creating a meaningful body of investigation that may result in a better and stronger Black Press in the United States and also generate knowledge that can be used to help alternative media elsewhere. More research on this topic is needed, but even more urgent is the development of the conditions for this research to be developed. Developing access to these fundamental news media outlets takes time and resources. Granting institutions need to be more intentional about creating not only call for proposals, but also working with the Black Press in making it easier for the media outlets to have the conditions to be researched. As seen in this study, a historic newspaper in St. Petersburg has closed its office and it is operating from the publisher's home, for example. That type of access requires a different level of trust from people who have been historically exploited. This study is just the very first step in a must needed and urgent line of inquiry.

\section{REFERENCES}

\section{Primary Sources}

Bellinger, Lorrie. Interview by Author. March 2, 2017.

Butler, Andreas. Interview by Author. March 7, 2017.

Fernandez, Duane C.. Interview by Author. March 7, 2017.

Johnson, Ethel. Interview by James Anthony Schnur. September 26, 2016

Johnson, Lyn. Interview by Author, March 3, 2017.

Morgan, Jenise. Interview by Author. February 23, 2017.

\section{Secondary Sources}

Abernathy, P. M. (2014). Saving Community Journalism: The Path to Profitability. Chapel Hill: The University of North Carolina Press.

About Us (2017) Florida Courier. Retrived, February 18, 2017, from http://flcourier. com/about-us/ 
Barthel, M. (2016). Newspapers: Fact Sheet. Pew Research Center. State of News Media 2016. Retrieved from http://www.journalism.org/2016/06/15/newspapersfact-sheet/

Becker, C. (1938). What is Historiography. The American Historical Review 44, No. 1: $20-28$.

Berger, A. A. (2014). Media and Communication Research Methods: An Introduction to Qualitative and Quantitative Approaches. San Francisco: SAGE.

Black Publisher Dies At 73: Cleveland Johnson, Jr., 1927-2001. (2001, August 2). The Weekly Challenger.

Butler, Andreas. (2016, December 29). They Always Deliver. Florida Courier. Retrieved from http://flcourier.com/2016/12/they-always-deliver/67

Cherry II, Charles W. (2016, March 3). Still Pleading Our Cause. Florida Courier. Retrieved from http://flcourier.com/2016/03/still-pleading-our-cause/

Dates, L. J. (ed.) (1990). Split Image: African Americans in the Mass Media. Washington: Howard University Press, 1990.

Deggans, E. (2005, December 17). Black Owned Florida Media Firm Plans Statewide Black newspaper. St. Petersburg Times. Retrieved from http://targetmarketnews.com/storyid12190501.htm

Drouzas, F. (2016, November 8). Large Turnout at The Weekly Challenger's Open House. The Weekly Challenger. Retrieved from http://theweeklychallenger.com/ large-turnout-at-the-weekly-challengers-open-house/

Garrison, B. (2001). Diffusion of online information technologies in newspaper newsrooms. Journalism 2(2), 221-239. doi:10.1177/146488490100200206

Guskin, E., Mitchell, A., \& Jurkowitz, M. (2013). African American: A Year of Turmoil and Opportunity. Pew Research Center. The State of the News Media 2013. Retrieved from http://www.stateofthemedia.org/2013/african-american-2/

Hancock, Dawson R., \& Bob Algozzine (2007). Doing Case Study Research: A Practical Guide for Beginning Researchers. New York: Teachers College Press.

Hansen, K., Paul, N., \& Neibergall, B. (2003). Survey of Large Newspapers Studies Information Practices. Newspaper Research Journal 24(4), 36-48. 
Happy Birthday, Cleveland Johnson. (2003, August 11). The Weekly Challenger. Hendricks, John Allen (Ed.). (2010). The Twenty-First-Century Media Industry: Economic and Managerial Implications in the Age of New Media. Maryland: Lexington Books.

History+Legacy. (2017, February 18). The Weekly Challenger. Retrieved from http://theweeklychallenger.com/about/

Jensen, K. B. (2002). A Handbook of Media and Communication Research: Qualitative and Quantitative Methodologies. New York: Routledge.

Kite-Powell, R. (2016). History \& Heritage: Area Newspapers Slow to Cover African-American Communities. Tampa Bay Times. Retrieved from http://www. tampabay.com/news/hum68

Mari, L. (2018). Technology in the Newsroom, Journalism Studies 19, no: 9: 13661389. doi: $10.1080 / 1461670 X .2016 .1272432$

Michaeli, E. (2016). The Defender: How the Legendary Black Newspaper Changed America: From the Age of the Pullman Porters to the Age of Obama. New York: Houghton Mifflin Harcourt.

Mitchell, A., Gottfried, J., Barthel, M., \& Shearer E. (2016). The Modern News Consumer: News Attitudes and Practices in the Digital Era. Pew Research Center. 4: 6. Retrieved from http://www.journalism.org/2016/07/07/the-modernnews-consumer/

Muhammad, Larry. (2003). The Black Press: Past and Present. Nieman Reports 57, no. 3: 13-16.

National Newspaper Publishers Association. (2016). Current members. Retrieved from http://nnpa.org/current-members/

Nielsen. (2015). Multifaceted Connections: African-American Media Usage Outpaces Across Platforms. Retrieved from https://www.nielsen.com/us/en/ insights/news/2015/multifaceted-connections-african-american-media-usageoutpaces-across-platforms.html

Peck, R., \& Wilson, J. (2008). St. Petersburg’s Historic African American Neighborhoods. Charleston: The History Press. 
Peck, R., \& Wilson, J. (2006). St. Petersburg’s Historic 22nd Street South. Charleston: The History Press.

Poindexter, P. M., \& McCombs M. E. (2000). Research in Mass Communication: A Practical Guide. Boston: Bedford/St. Martin's.

Pavlik, J. V. (2013). Innovation and Future of Journalism. Digital Journalism 1, no. 2: 181-193.

Rubin, R. B., Rubin, A. M., \& Piele, L. J. (2010). Communication Research: Strategies and Sources. Boston: Wadsworth.

Spyridou, L., Matsiola, M., Veglis, A., Kalliris, G., \& Dimoulas, C. (2013). Journalism in a state of flux: Journalists as agents of technology innovation and emerging news practices. International Communication Gazette 75, no. 1: 76-98.

Stroud, N. J. (2016). How Hyperlocal News Outlets Are Taking Shape across the U.S. American Press Institute. Retrieved from https://www.americanpressinstitute. org/publications/researchreview/hyperlocal-news/

Vogel, T. (Ed.). (2001). The Black Press: New Literacy and Historical Essays. New Jersey: Rutgers University Press.

Vogt, N. (2016). African American News Media: Fact Sheet. Pew Research Center. State of the News Media 2016, 80-86. Retrieved from http://assets.pewresearch. org/wp-content/uploads/sites/13/2016/06/30143308/state-of-the-news-mediareport-2016-final.pdf

Washburn, S. P. (1992). The African American Newspaper: Voice of Freedom. Illinois: Northwestern University Press.

The Mission Accomplished. (2005, December 1). Daytona Times.

The Weekly Challenger. Your Community News Source. Retrieved from http:// theweeklychallenger.com/about/

Wilson II, C. C. (2014). Whither the Black Press? Glorious Past, Uncertain Future. Delaware: Xlibris.

Wolseley, E. R. (1990). The Black Press, U. S. A. Ames: Iowa State. 